Компоненти бойових машин (кузов танка, основний бойовий танк, бронетранспортер) повинні бути виготовлені зі сталі підвищеної міцності $i$ твердості. Однак під час і після завершення процесу зварювання в сталі часто залишаються тріщини. Загартована $і$ відпущена сталь виготовляеться з гарячекатаної листової сталі (товщина $8 \mathrm{Mм}$ ), яка піддається термообробці гартуванням і відпуском для підвищення мічності і твердості. Новизна даного дослідження полягає в методі зварювання для створення зварного з'єднання, що має тонку структуру, високу міцність $i$ твердість. Це з'єднання проводиться методом ручного дугового зварювання в захисних газах. Досл дження проводилося за наступною схемою:

а) Периий крок. Підготовка зразка розміром 120×100×8 мм (рис. 3). Зразок поділяють на п'ять частин, кожна з яких має код SS (без термообробки), S750 (нагрів при $750{ }^{\circ} \mathrm{C}$ ), $S 800$ (нагрів при $800^{\circ} \mathrm{C}$ ), S850 (нагрів при $850{ }^{\circ} \mathrm{C}$ ) i $\mathbf{S 9 0 0}$ (нагрів при $900{ }^{\circ} \mathrm{C}$ ). ШІвиджість нагріву $=10^{\circ} \mathrm{C} / \mathrm{xв}$.

б) Другий крок. Нагрівання зразка $S 750$ при $750^{\circ} \mathrm{C}$ i витримка протягом 30 хвилин, потім гартування у водному середовищі. Те ж саме відноситься до зразків $S 800, S 850$ i $S 900$.

в) Третій крок. Дослідження металографії, твердості і енергї удару для SS, S750, S800, S850 i $S 900$.

г) Четвертий крок. Видалення першого иару зварного шва товщиною в половину пластини за допомогою ручного шліфувального верстата для кожного зразка, і продовження зварювання другого шару.

д) П'ятий крок. Другий шар зварних швів зиліфовують навпіл і приступають до остаточного зварювання.

Результати випробувань, проведених на сталі КСТА 500, включають хімічний склад основного металу, мікроструктуру і твердість для стандартного $і$ загартованого водою зварного з'єднання. Середньовуглецева сталь еквівалентна загартованій $і$ відпущеній сталі, використаної в даному дослідженні, $і$ має високу схильність до тріщиноутворення.

У мікроструктурі стандартного зварного з'єднання переважають мартенсит при гартуванні $і$ відпуску сталі, а також мартенсит, отриманий при термічній обробці гартування водою на зварному з'єднанні.

Зварене з'єднання, загартоване водою, показує більи тонку мікроструктуру зони термічного впливу, але метал зварного ива має тенденцію до жорстості і крихкості. Найбільша твердість досягається після гартування водою при $850{ }^{\circ} \mathrm{C}$, тобто основний метал=578 VHN, зона термічного впливу $=555 \mathrm{VHN}$, лінія оплавлення $=457 \mathrm{VHN} i$ метал зварного шва $=252 \mathrm{VHN}$

Ключові слова: аустеніт, крихкість, укрупнення, трішина, розтріскування, зміцнення, мартенсит, гартування, поліпшення, зварюваність

\title{
WELDING METHOD FOR HIGH CRACK SENSITIVITY OF Q\&T STEEL
}

\author{
Yurianto \\ Master of Technical Sciences, \\ Associate Professor* \\ E-mail: yurianto@undip.ac.id \\ Pratikto \\ Doctor of Technical Sciences, \\ Professor* \\ E-mail: prayone_adi@ub.ac.id \\ Rudy Soenoko \\ Doctor of Technical Sciences, \\ Professor* \\ E-mail: rudysoen@ub.ac.id \\ Wahyono Suprapto \\ Doctor of Technical Sciences, \\ Professor* \\ E-mail: wahyos@ub.ac.id \\ *Department of \\ Mechanical Engineering \\ Brawijaya University \\ J. Mayjend Haryono, 167, Malang, \\ Indonesia, 65145
}

Received date 20.06.2019

Accepted date 07.08.2019

Published date 31.08.2019
Copyright (C) 2019, Yurianto, Pratikto, Rudy Soenoko, Wahyono Suprapto This is an open access article under the CC BY license (http://creativecommons.org/licenses/by/4.0)

\section{Introduction}

High strength and hardness steels used to make components require high toughness such as pressure vessels and body panzers. However, these steels are susceptible to cracking during and after the welding process is complete. Sometimes these steels are difficult to weld, and the tricks welding is needed. The welding processes are always used to process in cutting and connecting to get the desired components of Quenched and Tempered Steel (Q\&T Steel), often used in armor steel because of the excellent strength and hardness. Q\&T Steel in this study is made of hot rolled plate steel (HRP Steels), which is quenched and tempered to obtain the strength and hardness. This steel is resistant to ballistic impact projectiles; therefore, hardness is the most important mechanical property, ballistic resistance AISI 4340 with a hardness of $50 \mathrm{HRC}=485 \mathrm{BHN}$ is armor steel [1]. Steel with higher hardness has low weldability. Researches on the heat-affected zone (HAZ) hardening in welded joints are mostly done; one of them is using the buttering method.

Therefore, the research is devoted to making welding methods in Q\&T Steel having significant crack sensitivity. The expected result is a welded joint that has better hardness than conventional, and hardening on HAZ welded joints produced.

\section{Literature review and problem statement}

Welding finish producing welded joints consist of weld metal (WM), HAZ, and

base metal (BM), each zone has heterogeneous structures. When welding is finished and cooled with water causing martensite formed in the HAZ, the hardness of refining grain HAZ (RGHAZ) and inter critical HAZ (ICHAZ) increases [2,3]. While other papers mention that HAZ consists of CGHAZ, RGHAZ, and inter-critical HAZ 
(ICHAZ) [4]. CGHAZ shows slightly increased in hardness and mixed-mode/microvoid mixed mode, but the toughness is equal to base metal [5]. Another paper states that microstructure heterogeneity influences the ballistic performance of welded joints [6]. Because CGHAZ is close to the fusion line, this area reaches maximum temperature, which permits the melting of carbides given base metals and granular growths [7]. High heat input causes the width of the HAZ to increase, but the contact angle decreases [8]. Refining microstructure increases in resistance of hydrogen embrittlement by more hydrogen trapped in the boundaries and reducing lattice density [9]. While the impact and fracture toughness increase, the temperature of quenching significantly increases [10]. The optimal combination of austenite and fine carbide grain sizes increases absorption energy, and fine austenitic grain sizes obtained previously at low temperatures, and fine carbide deposits at low tempering temperatures [11].

From the paper above, it is concluded that welded joints (HAZ as well) have heterogeneous microstructure, welding inlet heat affects the dimensions of the HAZ (higher heat input). Different microstructures reduce the joint strength, and homogeneous microstructures increase the joint strength. With water quenching on the welded joint, more delicate structures are obtained. While RGHAZ and RGHAZ hardness increased because of the martensite structure, and CGHAZ became hard and brittle (Fig. 1).

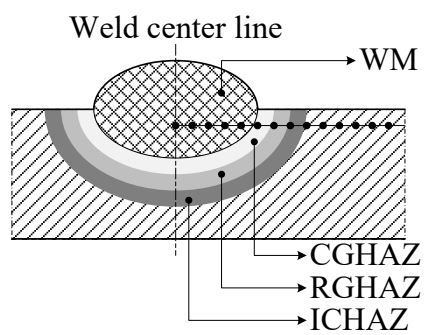

Fig. 1. Nomenclature of welded joint and hardness direction

The welding method that produces delicately structured joints is the novelty of this study.

Medium carbon steel, containing $(0.3-0.6) \%$ weight of carbon [12-14], moreover, is classified as steel that is difficult to weld. The coordinates of the point $(\mathrm{CE}, \mathrm{C})$ in the Graville Diagram (Fig. 2) is the location of the weldability of steels [3].

Weldability is the ability of metals to be welded without leaving defects or cracks [12]; the main influencing factors are composition, heat input, and cooling rate.

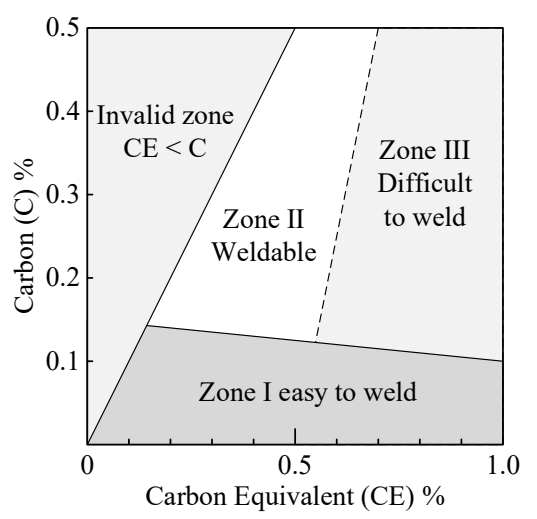

Fig. 2. Graville Diagram
This factor affects the growth of the granular structure, phase changes, expansion, and contraction, which ultimately determines the ability to be welded. Likewise, the selected filler metal will influence the stress distribution and strain on the weld joint [15]. The larger diameter fillers are needed, the higher the current and the higher the HAZ, while the smaller the diameter, the lower the current is needed and the smaller the HAZ. Carbon equivalent for Graville diagram is expressed by the formula (1) [3]:

$$
\mathrm{CE}=\mathrm{C}+\frac{(\mathrm{Mn}+\mathrm{Si})}{6}+\frac{(\mathrm{Cr}+\mathrm{Mo}+\mathrm{V})}{5}+\frac{(\mathrm{Ni}+\mathrm{Cu})}{15} .
$$

The optimal combination of austenite and fine carbide grain increases absorption energy, and fine austenitic grain sizes obtained previously at low temperatures, and fine carbide deposits at low tempering temperatures [7]. Absorbtion energy depends on the carbon percentage to a specific limit; steel with lower carbon content has high absorption energy [10]. Notches cause more damage to welded specimens, and there is no increase in Luders band on welds during production [9]. Various types of inclusions, such as oxides, carbides, nitrides, or sulfides, show the same effect on fatigue strength [11].

Sometimes this crack develops after welding is complete, i. e., heat tinted, $S$ and $P$ often cause this defect and usually occur in high alloy carbon steel. Cracks are physical damage due to stress, consist of hot cracks (UCS) and cold cracks $\left(P_{c m}\right)$ [4]. It is expressed by the formula (2),

$$
U C S=230 \mathrm{C}+190 \mathrm{~S}+75 \mathrm{P}+45 \mathrm{Nb}-12.3 \mathrm{Si}-5.4 \mathrm{Mn}-1 .
$$

Here $U C S$ is in \% weight. $U C S<10$, low crack susceptibility. $U C S>30$, the possibility of large cracks. If $U C S=10$ to 30 , welding could be adjusted,

$$
U C S=230 \mathrm{C}+190 \mathrm{~S}+75 \mathrm{P}+45 \mathrm{Nb}-12.3 \mathrm{Si}-5.4 \mathrm{Mn}-1 .
$$

If $P_{c m}<0.23 \%$ (low weld strength), and for $P_{c m}>0.35 \%$ (metal toughness to cold cracks is low). Recommended $P_{c m}=(0.25-0.30) \%$. Cracks during steel welding can be avoided by preheating, and post-heat, CE for different steels stated is expressed by the formula (4) [4]:

$$
\mathrm{CE}=\% \mathrm{C}+\frac{\% \mathrm{Mn}}{6}+\frac{\% \mathrm{Cr}+\% \mathrm{Mo}+\% \mathrm{~V}}{5}+\frac{\% \mathrm{Si}+\% \mathrm{Ni}+\% \mathrm{Cu}}{15} .
$$

If $\mathrm{CE}>0.35 \%$, preheats are recommended. Higher $\mathrm{CE}$ needs preheats and post-heats.

\section{The aim and objectives of the study}

The aim of the study is to create the technology for Q\&T Steel welded joint that has high crack susceptibility.

To achieve this aim, the following objectives are accomplished:

- to classify the material welded;

- to determine the weldability of the test material through the relationship between carbon equivalent and chemical elements; identify the test materials to hot and cold cracks;

- to perform metallography, hardness, and impact energy interpretation on standard and water quenched welded joints. 


\section{Material used and Welding method of Q\&T Steel to Q\&T Steel}

\section{1. Material Used}

The material of the study is Q\&T Steel welded joint made by PT. Krakatau Steel (Persero), Cilegon, Banten Province, Indonesia. Welded joints conducted by Manual Gas Metal Arc Welding - MGMAW, welding based on welding procedure specification (Table 1).

Table 1

Welding Procedure Specification

\begin{tabular}{|c|c|}
\hline Amperage & $(145-175) \mathrm{A}$ \\
\hline Base metal & Q\&T Steel to Q\&T Steel \\
\hline Gas shielded & $\mathrm{CO}_{2}$ \\
\hline Interpass & $(130-50){ }^{\circ} \mathrm{C}$ \\
\hline \multirow{3}{*}{ Filler metal } & AWS E71-T1 \\
\cline { 2 - 2 } & Wire diameter 1.2 \\
\cline { 2 - 2 } & SFA A5.20 \\
\hline Welding & GMAW \\
\hline Voltage & Voltage 22 V - 23 V \\
\hline Thick & 8 mm to 8 mm \\
\hline Technique & String \\
\hline Speed & $4.5-5.0$ (mm/second) \\
\hline Position & Position 1 G \\
\hline Polarity & DC \\
\hline
\end{tabular}

The configuration of welded joints in this study is shown in Fig. 3 (the type of fitting is $\mathrm{V}$ butt joint). Etching for metallographic purposes (microstructure images) uses $3 \%$ $\mathrm{HNO}_{3}$ and $97 \%$ alcohol.

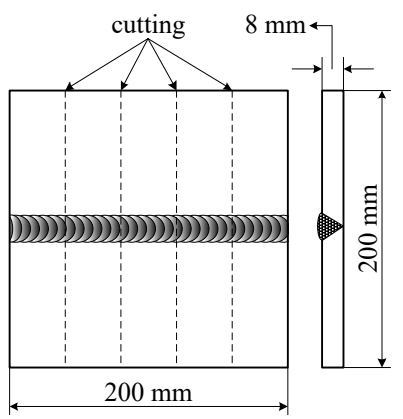

Fig. 3. $V$ butt joint

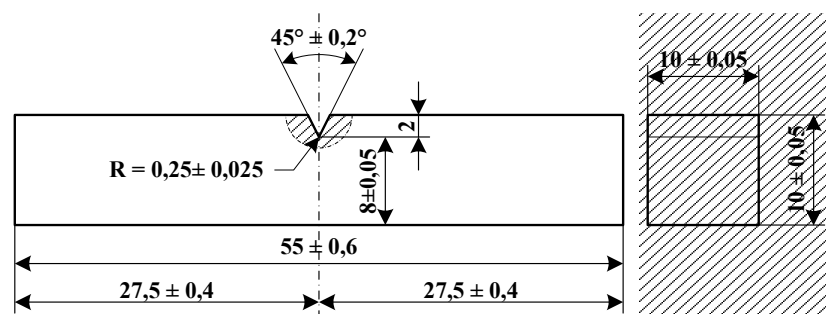

Fig. 4. ASTM E Charpy Impact test specimen [16]

Evaluation of the impact energy absorbed is shown in Fig. 4. The impact test in this study was intended to evaluate the impact energy absorbed by HAZ, not for this test focused on HAZ.

\section{2. Equipment used during the study}

The equipment used during the study is:

a) Mitsubishi Wire Eroding System type BA8, used for making impact test specimens.

b) MESSER Manual Gas Metal Arc Welding Machines for the welding process.

c) NABERTHERM heating furnaces (maximum temperature $1100{ }^{\circ} \mathrm{C}$ ) for austenitization of welded joints.

d) Optical Emission Spectrometer Machines ARL type 3460 , for chemical observation of BM.

e) NIKON Metallurgical Microscopes Epiphot, for microstructure observation.

f) ZWICK Zhu (500 g) for microhardness test.

g) WOLPERT Type PW 30/15, for impact test (focused on HAZ).

\section{3. Experimental procedures}

The experimental procedure of this study is represented in the block diagrams shown in Fig. 5.

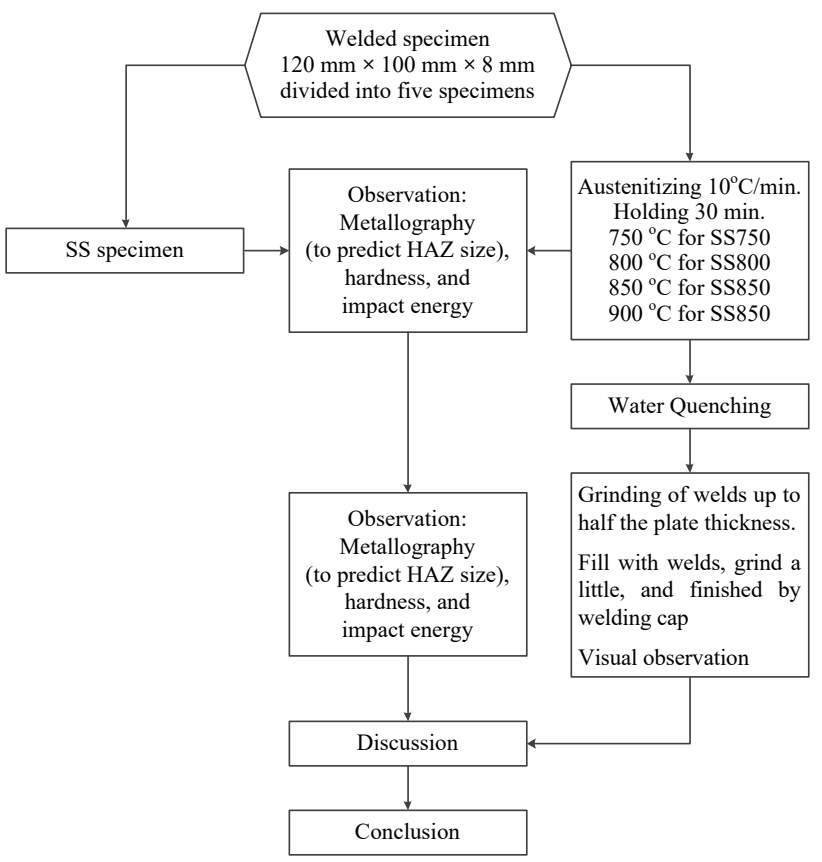

Fig. 5. Experimental Procedure

The scheme of investigation:

a) The first step. Preparation of welded specimens of $120 \times 100 \times 8 \mathrm{~mm}$ in size (Fig. 3). These specimens are divided into five parts, each is given code SS (without heat treatment), S750 (heating at $750{ }^{\circ} \mathrm{C}$ ), S800 (heating at $800{ }^{\circ} \mathrm{C}$ ), S850 (heating at $850{ }^{\circ} \mathrm{C}$ ) and S900 (heating at $900^{\circ} \mathrm{C}$ ). Heating rate used $=10{ }^{\circ} \mathrm{C} /$ minutes.

b) The second step. Heating specimen $\mathrm{S} 750$ at $750{ }^{\circ} \mathrm{C}$ and holding for 30 minutes, then quenching in the water medium. The same way is applied to specimens S800, S850, and S900.

c) The third step. Water quenching.

d) The fourth step. The observation of metallography, hardness, and impact energy for SS, S750, S800, S850, and S900 (Fig. 4).

e) The fifth step. The welds are ground up to half thickness of the plate. Filling the welds, and little grinding, and finishing using cap welding. 
f) The sixth step. Discussing the results of the observations.

g) The seventh step. Conclusions.

\section{3. 1. Welding on water quenched welded joints}

After metallography evaluation, the hardness evaluation is carried out by welding with the following steps:

a) Water quenched weld joint for the highest hardness value was selected.

b) Scrape to dispose of WM, FL, and CGHAZ using a hand grinding machine (best-done half-thick of BM welded plate).

c) Welding based on WPS Table 1.

d) The joint produced consists of FGHAZ.

\section{3. 2. Welding on proposed joint}

Welding on the water quenched weld joint. After metallography evaluation, the hardness evaluation is carried out by welding with the following steps:

a) Water quenched weld joint for the highest hardness value was selected.

b) Scrape to dispose of WM, FL, and CGHAZ using hand grinding machines (half thick of BM ground).

c) Welding based on WPS Table 1.

d) The joint produced consists of FGHAZ.

\section{3. 3. Welding on proposed joint}

The proposed steps of manufacture of welded joints are shown in Fig. $6, a-d$, and explained in the following steps:

a) The first step, making the $\mathrm{V}$ butt joint $60^{\circ}$ (Fig. 6, $a$ ) using grinding machines.

b) The second step, welding the first layer produces WM and HAZ, Fig. $6, b$.

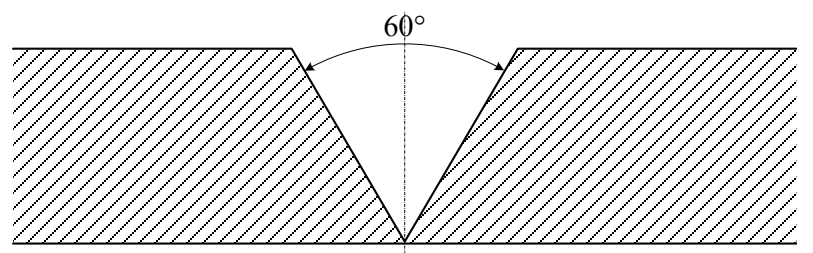

$a$

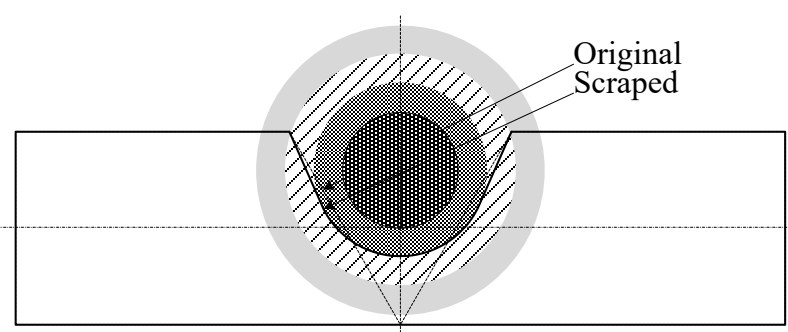

C c) The third step, scrape half of the first layer, as shown in Fig. 6, $c$ (after scrape, RGHAZ and ICHAZ left).

d) The fourth step, welding the second layer and producing WM and HAZ, and scraping half of the second layer; and finishing by cap welding.

From the first to the fourth step $(a-d)$, fine-grained weld joints are obtained, the proposed joint has better strength than the conventional joint.

\section{Research results}

The chemical composition shows only the main elements of the BM standard for research purposes (Table 2).

Table 2

Chemical composition (\% wt)

\begin{tabular}{|c|c|c|c|c|c|c|c|c|}
\hline $\mathrm{C}$ & $\mathrm{Cr}$ & $\mathrm{Mn}$ & $\mathrm{Mo}$ & $\mathrm{Ni}$ & $\mathrm{P}$ & $\mathrm{Si}$ & $\mathrm{S}$ & $\mathrm{Fe}$ \\
\hline 0.358 & 0.759 & 1.227 & 0.199 & 0.422 & 0.023 & 0.255 & 0.004 & 96.42 \\
\hline
\end{tabular}

Fig. 7, $a-11, a$ shows the macrostructure of a standard weld joint, which includes: 1 - HAZ; 2 - weld roots; 3 cracks; 4 - the boundary between weld roots - first layer; 5 - the boundary between BM and HAZ; 6 - the boundary between the first and second layers; 7 - WM; 8 - Porous between HAZ and WM.

$\mathrm{BM}$ hardness before and after water quenching includes BMstd $=430 \mathrm{VHN} ; \mathrm{BM} 750=451 \mathrm{VHN} ; \mathrm{BM} 800=554 \mathrm{VHN}$; $\mathrm{BM} 850=578 \mathrm{VHN}$ and BM900 $=555 \mathrm{VHN}$, can be plotted in the bar diagram as shown in Fig. 12.

HAZ hardness before and after water quenching includes HAZstd $=378$ VHN; HAZ750 $=494$ VHN; HAZ800 $=$ $=538 \mathrm{VHN} ; \mathrm{HAZ} 850=555 \mathrm{VHN}$, and HAZ900 $=551 \mathrm{VHN}$, all of them are shown in the bar diagram in Fig. 13.

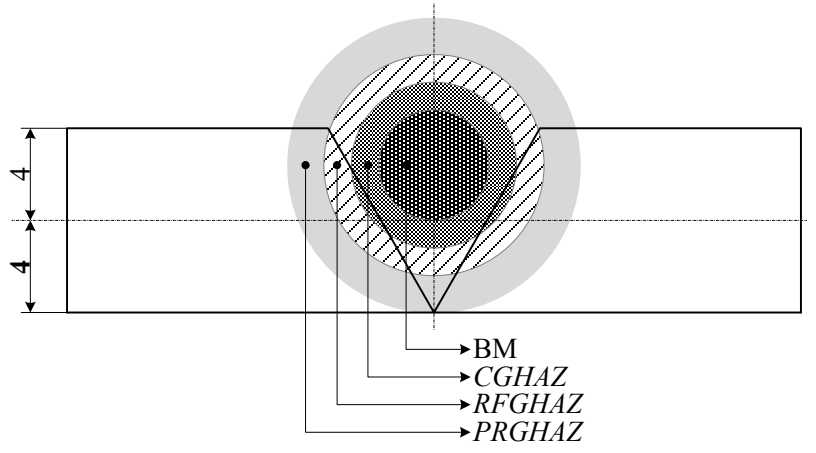

$b$

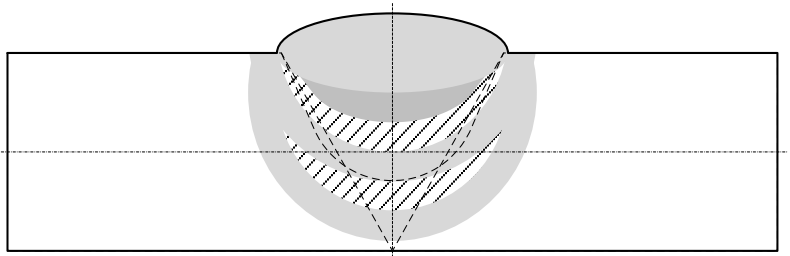

d

Fig. 6. Welding steps: $a-$ Manufacture of butt weld joint, $b-$ Welding and finishing by water quenching, $c-$ WM and CGHAZ both disposed of using hand grinding machines, $d-$ Closing weld (welding cover (capping) 


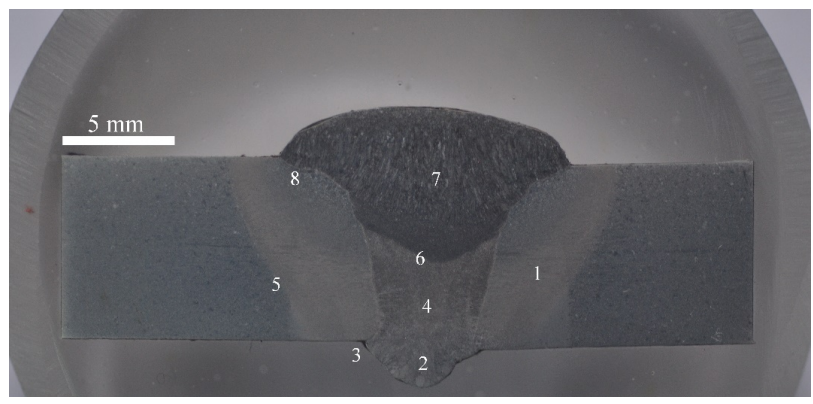

$a$

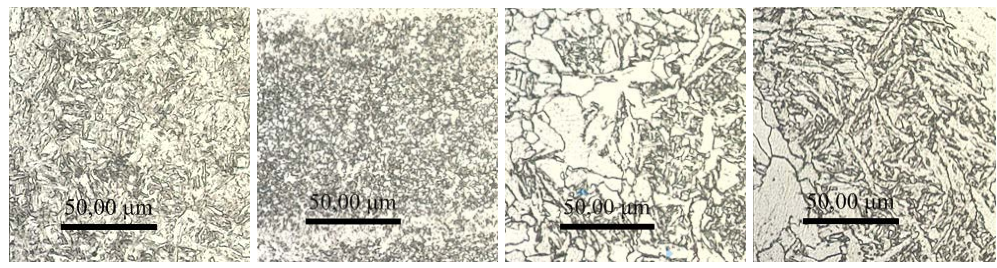

$d$

Fig. 7. Standard welded joint macro and microstructure: $a-$ Macrostructure, $b-\mathrm{BM}, c-\mathrm{HAZ}, d-$ Fusion line, $e-$ WM
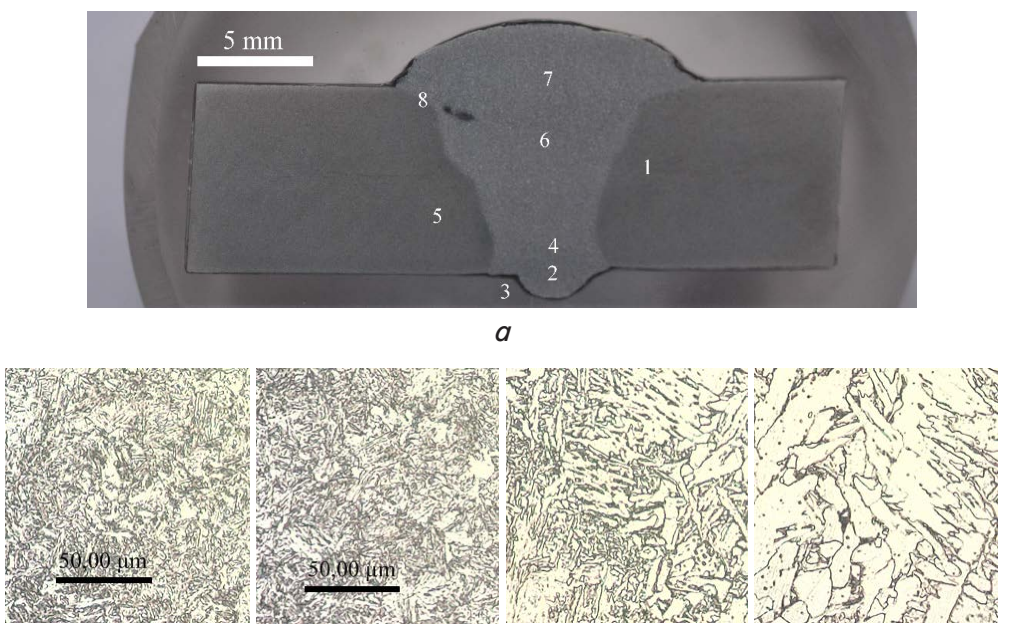

$b$

c

$d$

$e$

Fig. 8. Quenched $750^{\circ} \mathrm{C}$ welded joint microstructure: $a-$ Macrostructure, $b-\mathrm{BM}, c-\mathrm{HAZ}, d-$ Fusion line, $e-$ WM

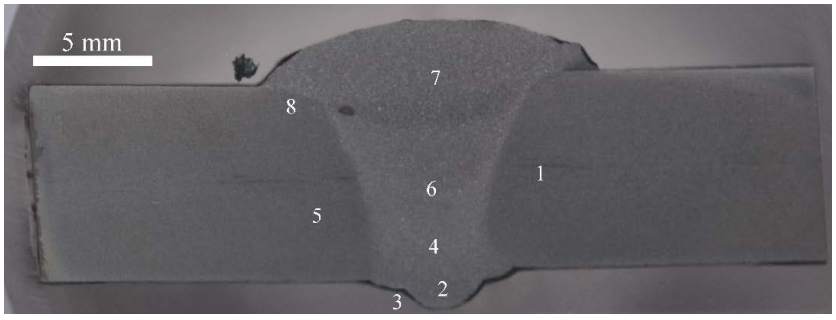

$a$

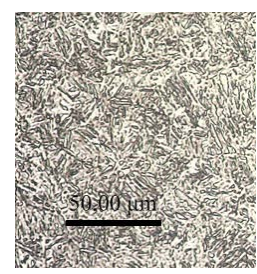

$b$

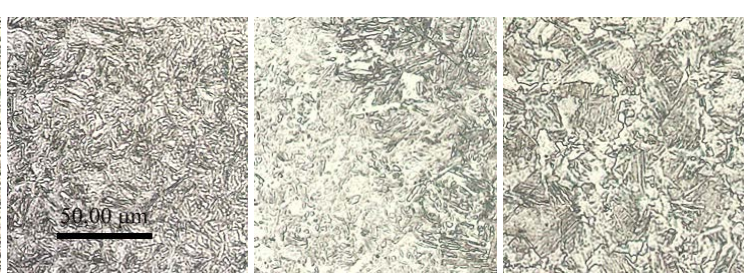

$d$

e

Fig. 9. Quenched $800^{\circ} \mathrm{C}$ welded joint microstructure: $a-$ Macrostructure, $b-\mathrm{BM}, c-\mathrm{HAZ}, d-$ Fusion line, $e-$ WM 


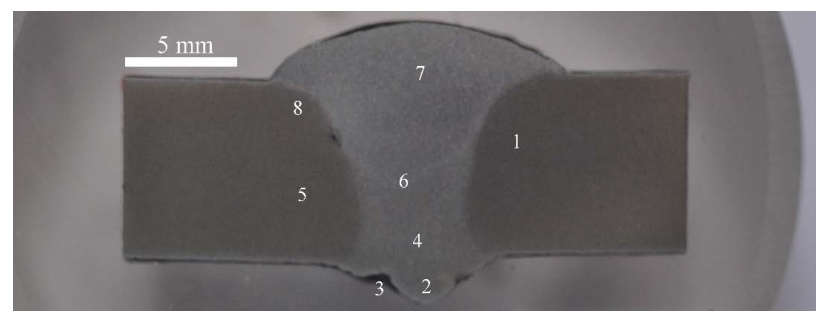

$a$

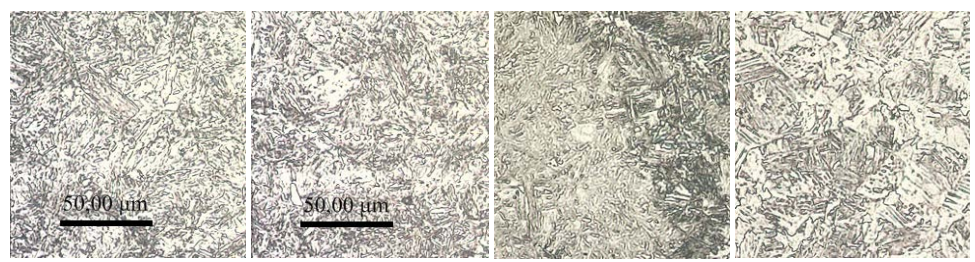

$b$

c

d

e

Fig. 10. Quenched $850^{\circ} \mathrm{C}$ welded joint microstructure: $a-$ Macrostructure, $b-\mathrm{BM}, c-\mathrm{HAZ}, d-$ Fusion line, $e-\mathrm{WM}$

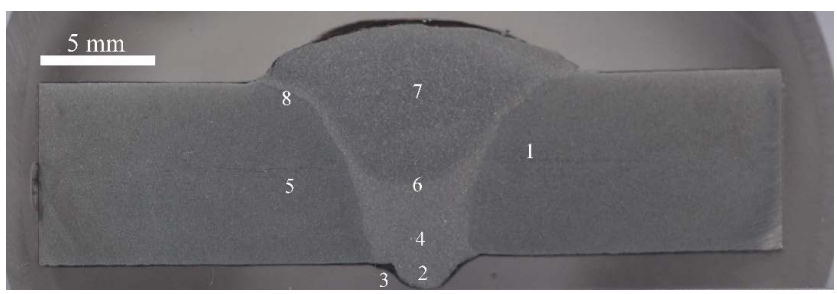

$a$

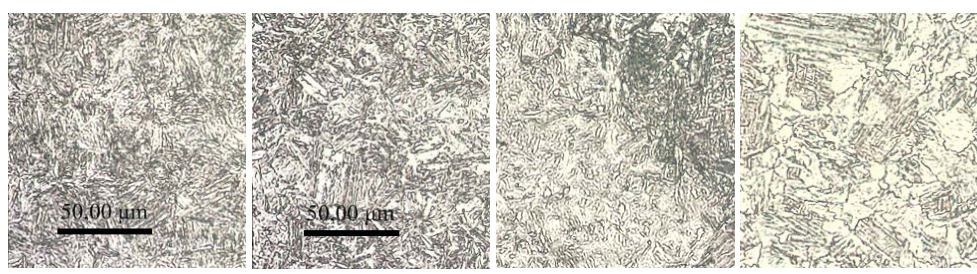

$b$

c

$d$

$e$

Fig. 11. Quenched $900{ }^{\circ} \mathrm{C}$ welded joint microstructure: $a-$ Macrostructure, $b-\mathrm{BM}, c-\mathrm{HAZ}, d-$ Fusion line, $e-\mathrm{WM}$

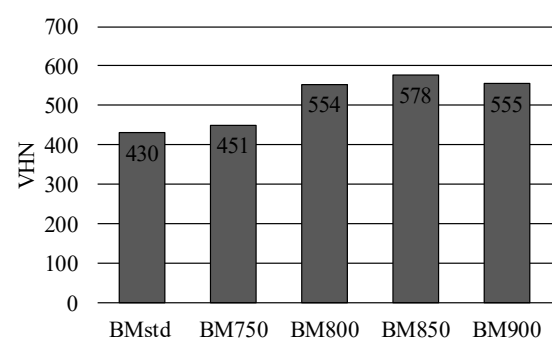

Fig. 12. BM hardness

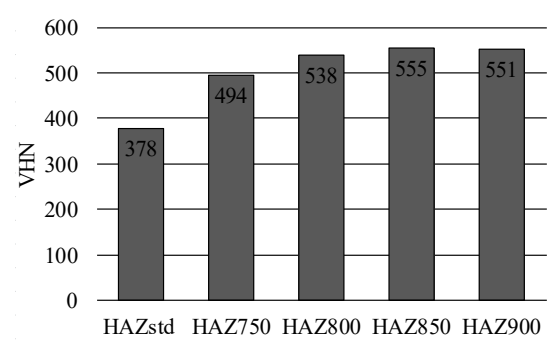

Fig. 13. HAZ hardness
WM hardness before and after water quenching includes: WMstd=219 VHN; WM750 $=446$ VHN; WM800= $=460 \mathrm{VHN} ; \mathrm{WM} 850=457 \mathrm{VHN}$, and $\mathrm{WM} 900=533 \mathrm{VHN}$, and is shown in the bar diagram in Fig. 14.

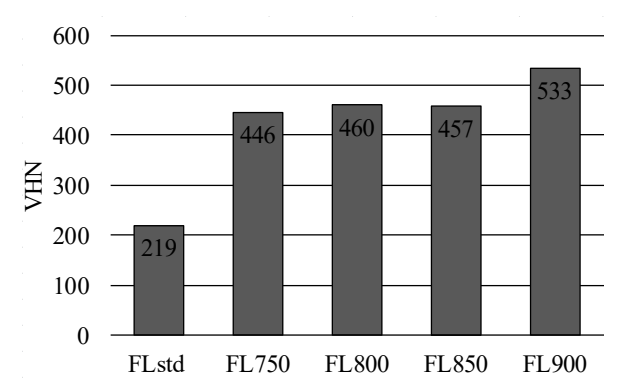

Fig. 14. FL hardness

WM hardness before and after water quenching includes: WMstd $=190 \mathrm{VHN} ; \mathrm{WM} 750=299 \mathrm{VHN}$; WM $800=278$ VHN; WM850=252 VHN, and WM900= $=242 \mathrm{VHN}$, and is shown in the bar diagram in Fig. 15 . 


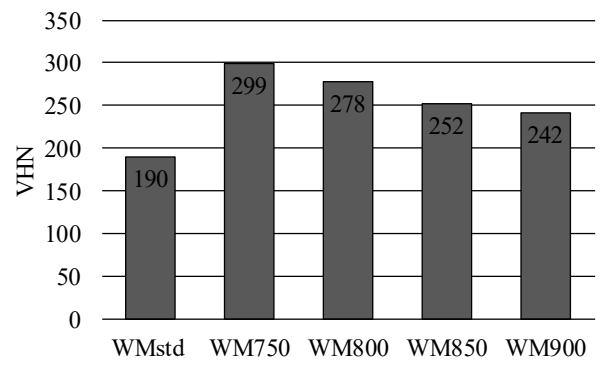

Fig. 15. WM hardness

Impact energy absorbed by HAZ before and after water quenching includes: IEstd $=29.50$ Joule; IE750 $=25.50$ Joules; IE $800=23.50$ Joules; IE $850=16.50$ Joules, and IE900= $=15.50$ Joules, can be shown in the bar diagram as shown in Fig. 16.

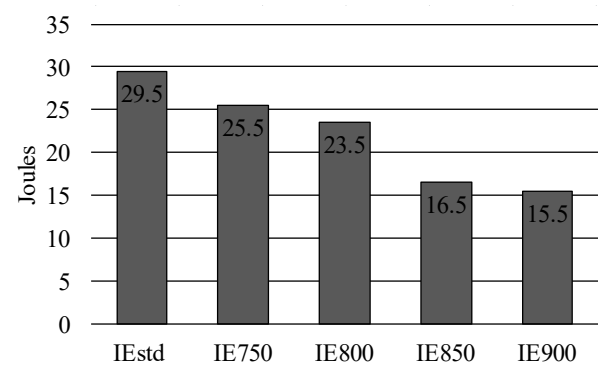

Fig. 16. Impact Energy Absorbed of HAZ

\section{Discussion of the research results}

Based on the elements contained in Table 2, Q\&T Steels are classified as medium carbon steel. Using the formula (1) and (2), the Ar3 and Ms values are obtained, as shown in Table 3.

Evaluation of cracks during and after welding for Q\&T Steel was carried out by formula (3) and (4), crack susceptibility is obtained and shown in Table 4.

Table 3

$\mathrm{Ar}_{3}$ and Austenite temperature

\begin{tabular}{|c|c|c|}
\hline No. & Information & Unit ${ }^{\circ} \mathrm{C}$ \\
\hline 1 & $\mathrm{Ar}_{3}$ (transformation temperatures) & 650 \\
\hline 2 & $\begin{array}{c}\text { Austenite temperature used } \\
\text { (quenching temperature) }\end{array}$ & $750,800,850,900$ \\
\hline
\end{tabular}

Table 4

Cold and hot cracking susceptibility of Q\&T Steel

\begin{tabular}{|c|c|c|}
\hline Types of cracks & Value & Description \\
\hline Cold crack (Pcm) & 7.51 & $\begin{array}{c}>0,35 \%, \text { metal is not tough on } \\
\text { cold cracks }\end{array}$ \\
\hline Hot crack (UCS) & 75 & $>30$, high crack susceptibility \\
\hline
\end{tabular}

This steel does not contain boron, so it is cheaper and easier to heat to obtain the desired hardness. In general, steels with $\mathrm{C}>0.20 \%$ are considered heat-treatable steel. To optimize the performance of steel for a particular purpose, optimization of the quench and temper parameters to the selected response can be done (for example against hardness vs. wear, hardness vs. impact energy and impact energy vs. wear).
$\mathrm{Ar}_{3}\left(650^{\circ} \mathrm{C}\right)$ as a reference to obtain an austenite structure that is transformed into the desired martensite to increase HAZ hardness. Slightly above $\mathrm{Ar}_{3}$ (close to $\mathrm{Ar}_{3}$ ) is refiner austenite zone obtained, and when water quenching finishes, fine martensite is produced. The higher the austenite temperature, the coarser austenite obtained, and coarse martensite is produced at the end of water quenching.

This steel is quite high in cracking susceptibility, especially in the welded joints. Therefore, the welding process must be carried out in a unique way to avoid softening of the HAZ welding joint.

The Q\&T Steel weldability properties were evaluated using the relationship of points $(\mathrm{CE}, \mathrm{C})$ on the Graville diagram. Based on formula (6), $\mathrm{CE}=0.825$ is obtained and the point $(\mathrm{CE}, \mathrm{C})$ shows the zone that Q\&T Steel is difficult to weld. From the evaluation of cracks in Q\&T Steel, the crack susceptibility is quite high and tricks to do welding.

The difference between dark and light images shows a different microstructure. (Dark image shows high hardness and brittle, and bright colors show fine structures). Cracks (3) are due to hot cracking during the welding process by the content of alloying elements (due to the extremely high cracking susceptibility of the steel $U C S=75$. Hot cracks occur at $700{ }^{\circ} \mathrm{C}$ due to freezing of the weld metal and the release of stress at the HAZ. Weld cracks are cold cracks due to phases in the HAZ, diffusion of hydrogen and stresses in the weld area. Pores between WM and HAZ are due to contamination of dirt and trapped air forming cavities and essential using preheat before the BM microstructure (Fig. 7, $b$ ) shows the dominance of martensite caused by previous water quenching. HAZ has finer micro-structure than BM (Fig.7, $c$ ); it is caused by heating after water quenching. FL microstructures are coarser than WM, both zones have Witmannstaeten patterns (Fig. 7, $d, e$ ).

Fig. 8, $a$ shows the microstructure for Quenched $750{ }^{\circ} \mathrm{C}$ welded joint. As a result, $750{ }^{\circ} \mathrm{C}$ water quenching causes HAZ and BM grain density (1). Roots crack compaction occurs (2), and cracks are reduced (3). The boundary between weld roots and first layer appears dense together (4). The merging of BM and HAZ boundaries occurs (5). The boundary between the first and second layers merges (6). The texture in WM (7) is small. Pores between HAZ and WM seem to be dense (8).

There was a sealing at the boundary due to fine-grain after water quenching, and porous area as well. The dominance of martensite by previous water quenching is shown in Fig. $8, b$. The HAZ structure (Fig. 8, c) is similar to BM; caused some martensites defused during the austenitization process. The microstructure of FL (Fig. 8, d) is coarser than BM and HAZ because of the transition between structures (from WM to HAZ). The WM structure (Fig. 8,e) shows the growth of new phase grains at the BM boundary. The difference in grain structure will reduce the strength of the joint.

Fig. 9, $a$ shows the interface boundaries close together because of the fine grain that the stronger in welded joints. The porosity is reduced (when water quenching $750{ }^{\circ} \mathrm{C}$ ), mean between the structures pressed together by austenitization at $800{ }^{\circ} \mathrm{C}$. Compact structure (including porous) will increase strength and hardness. Martensite dominates base metal because of previous water quenching and water quenching at $800{ }^{\circ} \mathrm{C}($ Fig. $9, b)$. Water quenching at $850{ }^{\circ} \mathrm{C}$ results in the refinement of the grain structures. The similar structure of $\mathrm{HAZ}$ and $\mathrm{BM}$ and is dominated by martensite 
(Fig. 9,c). FL (close to WM) has grain structures caused by heat induced by WM and arc (Fig. 9, $d$ ), and the coarse grain structures are produced. Because of the coarse grain, then FL has a high cracking susceptibility. WM is getting finer-structure due to dense in granular structure, and the brittleness decreases (Fig. 9, $d$ ). When austenitization reached the austenite zone and followed water quenching, residual compression stress left and compacting the grain structures occurs, and mechanical hardening is produced. Transformation of austenites to martensite during the water quenching process and metallurgical hardening is produced. So, two hardenings are very influential in compacting the granular structure.

Fig. 10, $a$ shows the macrostructure of a welded joint that is quenched by water at $850^{\circ} \mathrm{C}$. The smoothing of the grains causes $\mathrm{HAZ}$ and BM to join (1). Compaction occurs in (2), (3), and (4). The merging of BM and HAZ boundaries occurs (5). The merging of the boundary between the first and second layers occurs (6). Texture smoothing also occurs in WM (7). The porous between HAZ and WM close together (8). Fig. 10, $b$ is dominated by martensite. The microstructure of HAZ is similar to BM. Fig. 10, $d$ shows FL is a thin layer that is prone to cracking. Fig. 10, $e$ shows a WM with a rough structure caused by a high heat arc. Water quenching at $850 \mathrm{C}$ results in compaction and recovery of cracks between the structures. The strength and hardness of the joint increase due to water quenching.

At $900{ }^{\circ} \mathrm{C}$ water quenching, the sealing also occurs the same as at $850{ }^{\circ} \mathrm{C}$, but the result is refined structure. So it can be said that when increasing the austenite temperature, refined structures are produced. The fine structure will increase compaction, strength, and ductility.

Hardness tends to increase with increasing austenite temperature to $850{ }^{\circ} \mathrm{C}$ and decreases at $900{ }^{\circ} \mathrm{C}$. BMstd hardness increases because of martensites produced by the previous water quenching process when producing Q\&T Steel. Increased hardness to martensite grains is getting coarse because austenite growth occurs. The maximum hardness reached $850{ }^{\circ} \mathrm{C}$ and decreased at $900{ }^{\circ} \mathrm{C}$, as shown in Fig. 12 .

HAZ hardness increases by increasing the austenite temperature and decreases slightly at $900{ }^{\circ} \mathrm{C}$. The decrease is caused by the grain growth of austenite and the highest hardness occurs at $850{ }^{\circ} \mathrm{C}$. Hardness increase occurs in the formation of martensite.

FL hardness tends to increase with austenite temperature increasing but decreases slightly at $850{ }^{\circ} \mathrm{C}$. The high- est hardness is reached at $900{ }^{\circ} \mathrm{C}$ (austenite grain growth occurs). Because FL is the smallest area and has a lower hardness have a coarse grain structure, this part is brittle and low strength.

Hardness increases from standard conditions to temperatures of $750{ }^{\circ} \mathrm{C}$ (highest hardness) and decreases to $900{ }^{\circ} \mathrm{C}, \mathrm{WM}$ has a coarse grain. Austenite temperature increases, and hardness is decreased due to porosity. Porosity is caused by the vapor and slag trapped in molten metal.

The austenite temperature increases the impact of energy decrease, and the hardness increases. The IE decrease means that the impact energy absorbed by the HAZ decreases with increasing austenite temperature (softening increased).

\section{Conclusions}

1. The material of the study (Q\&T Steel) was equivalent to medium carbon steels.

2 . Through the relationship between $\mathrm{CE}=0.825$ and $\mathrm{C}=0.358$, the point $(\mathrm{CE}, \mathrm{C})$ in the Graville Diagram expresses that medium carbon steel is difficult to weld. The steel of the study has a high susceptibility to cold and hot cracks, 7.51 and 75 , respectively.

3. The microstructure of standard welded joints is dominated by martensite when making Q\&T Steel, and the microstructures of HAZ, FL and WM tend to be coarse. After water quenching, the refined HAZ microstructure is obtained and WM tends to be coarse (even brittle). Standard hardness is $\mathrm{BM}=430 \mathrm{VHN}, \mathrm{HAZ}=378 \mathrm{VHN}$, $\mathrm{FL}=219 \mathrm{VHN}$ and $\mathrm{WM}=190 \mathrm{VHN}$. The highest hardness is achieved after $850{ }^{\circ} \mathrm{C}$ water quenching, namely $\mathrm{BM}=578 \mathrm{VHN}, \mathrm{HAZ}=555 \mathrm{VHN}, \mathrm{FL}=457 \mathrm{VHN}$, and $\mathrm{WM}=252 \mathrm{VHN}$. Impact energy absorbed by standard HAZ weld joint is 29.50 Joules drop after water quenching at $850{ }^{\circ} \mathrm{C}$ is 16.50 Joules. The grain structure gets smoother with increasing austenite temperature in water quenching, strength, and ductility increase.

\section{Acknowledgments}

The authors would like to thanks Mr. Agus Kusmanto, who at the time was the Head of Production Department 1, Division of Special Vehicles, PT. Pindad (Persero), Indonesia, for support of materials in this study.

\section{References}

1. Demir, T., Übeyli, M., Yıldırım, R. O. (2008). Effect of Hardness on the Ballistic Impact Behavior of High-Strength Steels Against 7.62-mm Armor Piercing Projectiles. Journal of Materials Engineering and Performance, 18 (2), 145-153. doi: https://doi.org/ 10.1007/s11665-008-9288-3

2. Bailey, N., Coe, F. R., Googh, T. G., Hart, P. H. M., Jenkins, N., Pargetter, R. J. (1973). Welding steels without hydrogen cracking. Abington Publishing and ASM International.

3. Datta, R., Mukerjee, D., Jha, S., Narasimhan, K., Veeraraghavan, R. (2002). Weldability Characteristics of Shielded Metal Arc Welded High Strength Quenched and Tempered Plates. Journal of Materials Engineering and Performance, 11 (1), 5-10. doi: https:// doi.org/10.1361/105994902770344321

4. ASM Handbook. Properties and Selection: Irons, Steels, and High Performance Alloys. Vol. 6. Copyright ASM International, 1996, 246-247.

5. Jefferson, T. B.; O’brien, R. L. (Ed.) (1997). Jefferson's Welding Encyclopedia. American Welding Society, 758. 
6. Yue, X., Lippold, J. C., Alexandrov, B. T., Babu, S. S. (2012). Continuous Cooling Transformation Behavior in the CGHAZ of Naval Steels. Welding Journal, 91 (3), 67S-75S.

7. Mani, E., Udhayakumar, T. (2018). Effect of prior austenitic grain size and tempering temperature on the energy absorption characteristics of low alloy quenched and tempered steels. Materials Science and Engineering: A, 716, 92-98. doi: https:// doi.org/10.1016/j.msea.2018.01.020

8. Yang, J., Song, Y., Lu, Y., Gu, J., Guo, Z. (2018). Effect of ferrite on the hydrogen embrittlement in quenched-partitioned-tempered low carbon steel. Materials Science and Engineering: A, 712, 630-636. doi: https://doi.org/10.1016/j.msea.2017.12.032

9. Chen, G., Luo, H., Yang, H., Han, Z., Lin, Z., Zhang, Z., Su, Y. (2019). Effects of the welding inclusion and notch on the fracture behaviors of low-alloy steel. Journal of Materials Research and Technology, 8 (1), 447-456. doi: https://doi.org/10.1016/j.jmrt.2018.04.005

10. Qasim, B. M., Khidir, T. C., F. Hameed, A., Abduljabbar, A. A. (2018). Influence of heat treatment on the absorbed energy of carbon steel alloys using oil quenching and water quenching. Journal of Mechanical Engineering Research and Developments, 41 (3), $43-46$. doi: https://doi.org/10.26480/jmerd.03.2018.43.46

11. Schumacher, J., Clausen, B., Zoch, H.-W. (2018). Influence of inclusion type and size on the fatigue strength of high strength steels. MATEC Web of Conferences, 165, 14003. doi: https://doi.org/10.1051/matecconf/201816514003

12. Leister, B. M., Dupont, J. N. (2012). Fracture Toughness of Simulated Heat-Affected Zones in NUCu-140 Steel. Welding Journal, 91, 53-s-58-s.

13. Shen, S., Oguocha, I. N. A., Yannacopoulos, S. (2012). Effect of heat input on weld bead geometry of submerged arc welded ASTM A709 Grade 50 steel joints. Journal of Materials Processing Technology, 212 (1), 286-294. doi: https://doi.org/10.1016/ j.jmatprotec.2011.09.013

14. Madhusudhan Reddy, G., Mohandas, T., Papukutty, K. . (1998). Effect of welding process on the ballistic performance of highstrength low-alloy steel weldments. Journal of Materials Processing Technology, 74 (1-3), 27-35. doi: https://doi.org/10.1016/s09240136(97)00245-8

15. Yanet, M., Mónica, Z. (2015). Microstructure Characterization of Heat Affected Zone in Single Pass Welding in 9Cr-1Mo Steels. Procedia Materials Science, 8, 904-913. doi: https://doi.org/10.1016/j.mspro.2015.04.151

16. ASTM E23 - 07a. Standard Test Methods for Notched Bar Impact Testing of Metallic Materials (2007). ASTM International, West Conshohocken, PA. doi: https://doi.org/10.1520/e0023-07a 